theory is inapplicable because fragmentation of the meteor occurs, leading to greatly increased radiation and quicker evaporation. Bodies large enough to enter the denser region of the atmosphere, where they acquire a compressed-air cap ahead of them which largely shields them from the direct blows of atmospheric molecules, are those producing trails much brighter than the brightest stars, and they are observed far too rarely for any systematic knowledge of their aerodynamics to have been found. The larger ones reach the Earth in the form of meteorites, which are mostly of irregular shape, often pitted with deep, roughly spherical holes. Prolonged discussion at the meeting of whether information concerning the aerodynamical experiences of these bodies can be found led to no very helpful conclusions.

The last lecture was by Dr. Wayland Griffith, of the Palmer Physical Laboratory, Princeton University, where much of the pioneering work with shock tubes was done under the direction of Dr. Walker Bleakney. Dr. Griffith has been studying in Britain for the past year. He described fundamental work on the experimental verification of the RankineHugoniot equations for a shock wave passing through various gases, using their known equilibrium thermodynamies. This work shows, for example, that although the transverse vibrations of the carbon dioxide molecule are excited in such experiments with a relaxation time equal to that found from acoustic attenuation work, the longitudinal (valence) vibrations still remained unexcited after a time long compared with this (of the order of milliseconds).

Dr. Griffith discussed experimental determinations in shock tubes, by Davidson, Hornig and others, of dissociation rates, and gave theories, both of the chemical kinetics of dissociation, and of the fluid dynamics of the process which may be postulated to infer the rates from the experimental observations. He then described the work which had been done in Dr. A. R. Kantrowitz's laboratory at Cornell University on ionization produced by strong shock waves in argon. The observed time-delays before equilibrium ionization has suggested improved approaches to the kinetics of the ionization process. The luminosity of the shock front itself, which has sometimes been observed, is the result of impurities. The measurements of conductivity of a gas with high electron density has shown satisfactory agreement with theory.

In his concluding address Prof. Devons remarked on the impressive degree of collaboration between applied mathematicians, physicists, chemists and engineers which seems already to have taken place in this field. He emphasized, however, that an even greater degree of co-operation will be necessary, both if the maximum effectiveness for man-made projectiles travelling at extreme speeds is to be achieved, and if the shock tube is to be fully utilized for uncovering the secrets of high-speed gas reactions.

\title{
THE WEIZMANN INSTITUTE OF SCIENCE
}

$\mathrm{T}$ O mark the tenth anniversary of the foundation of the Weizmann Institute of Science, the Board of Governors, together with representatives of supporting groups in Great Britain, the United States, Canada and Switzerland, held a conference in London early in July.

The Weizmann Institute had its origin in the Daniel Sieff Research Institute at Rehovoth, a town about twelve miles south of Tel Aviv. The Sieff Research Institute had been set up in 1934 by $\mathrm{Mr}$. and Mrs. Israel N. Sieff, of London, as a memorial for their youngest son, who had died the year before. Dr. Chaim Weizmann (1874-1952), with whom Mr. and Mrs. Sieff consulted before founding the Institute, assumed its direction and was responsible for its first scientific programme.

In 1944 a group of Dr. Weizmann's friends in the United States launched a project to mark his seventieth birthday and raised five million dollars for the purpose. It was then decided to establish the Weizmann Institute of Science, the Daniel Sieff Research Institute being retained as the parent unit.

The foundation stone for the expanded establishment was laid on June 3, 1946, and the Weizmann Institute was formally inaugurated and began functioning in November 1949. The Institute now covers an area of some ninety acres, with four large buildings in addition to the parent structure, the Sieff Institute, and an Institute of Physics in construction. Compared with the Sieff Institute's original staff of ten scientists and some twenty technical and administrative workers, there are now 130 scientists and more than 350 other personnel.
The recent conference was divided into five sessions. Two of these sessions were under the chairmanship respectively of Sir Francis Simon and Sir Solly Zuckerman, and dealt with the Institute's scientific interests.

The Institute engages primarily in research and has no teaching responsibilities, apart from the affiliation of several of its departmental heads to the Hebrew University in Jerusalem as visiting professors. Its main research interests are in the exact sciencesmathematics, physics, nearly all branches of chemistry, and some branches of biology. The desire has lately been expressed by scientific staff at various levels for the introduction of postgraduate teaching as a means of augmenting Israel's reservoir of trained professional man-power and also as a stimulus to their own work. As a result of a recommendation of a Committee which was set up under the chairmanship of Sir Ben Lockspeiser, the Board of Governors has now decided to provide more opportunities for postgraduate training than were available in the past. This Committee also recommended "that the provision of special courses as a useful service for the country, as, for example, in the fields of radio chemistry, plastics chemistry, electronic computing and numerical analysis, be encouraged within the capacity of the Institute". Some time ago the U.S. Government decided to include support of the Radioisotope School at the Weizmann Institute, for training professional men in the use of isotopes, as part of a series of grants it was making for higher learning and research in Israel.

In addition to the heads of departments of the Institute who came from Israel, the conference was 
attended, among others, by Prof. P. M. S. Blackett, London; Prof. E. B. Chain, Rome; Prof. Louis Fieser, Harvard University; Prof. H. A. Krebs, Oxford ; Sir Ben Lockspeiser ; Prof. David Rittenberg, New York ; and Sir Robert Robinson, London. Prof. Saul Adler, of the Hebrew University at Jerusalem, and Prof. S. G. Zondek, of Tel Aviv, attended in their capacities as members of the Institute's Board of Governors.
In addition to the resolution extending postgraduate teaching, the Board of Governors dealt with and decided upon certain administrative reorganization and the consolidation of the financing policy.

When eventually put into effect, the postgraduate teaching curriculum will be of great advantage to Israel, which has still to develop and broaden this aspect of its higher learning.

\section{OBITUARIES}

\section{Sir Henry Guy, C.B.E., F.R.S.}

Britais has always been rich in engineers whose interests lay in the field of practical construction. It has never been quite so prolific in engineers concerned with engineering science. Although in recent years ill-health put a severe restriction on his activities, the death on July 20 of Sir Henry Guy has removed one from the smaller band of those who took an active and prominent part in the encouragement and organization of engineering research.

His interest was no theoretical interest. It was founded on a wide practical experience as an engineering designer. For more than twenty years he occupied the responsible position of chief mechanical engineer to the Metropolitan-Vickers Electrical Co., Ltd., where, in the quest for ever-increasing thermal efficiency, he designed steam turbines which were not only notable advances in regard to the steam pressures and superheat temperatures that were used, but also in regard to the size of the units. The $100,000-\mathrm{kW}$. turbo-generator which is now accepted as the standard unit for large power stations had already been designed by Sir Henry Guy and constructed by his Company during the 1930's. When the Soviet Government invited competitive designs for a turbo-generator unit to be used as a basis for the development of power stations in the U.S.S.R., it was his design put forward by Metropolitan-Vickers that won the award and the contracts against world-wide competition.

No one was better able to assess the gaps in our knowledge of engineering science than Sir Harry, as his opinion was fortified by his recollection of those many occasions when faith in his own intuition had to replace the experimental knowledge that was wanting.

When the Advisory Council of the Department of Scientific and Industrial Research, of which Sir Henry Guy was a member at the time, considered during the last year of the Second World War how the pattern of research should be developed in Britain, the need for more research on engineering subjects was specially emphasized. A committee under Sir Henry's chairmanship was set up to consider what practical action should be taken, and it was the recommendation of the Guy Committee that led to the foundation of the Mechanical Engineering Research Laboratory now sited at East Kilbride.

No one better could have been chosen as chairman for this purpose. His wide and detailed knowledge of engineering in its many branches made him visualize the sections into which research on fundamental science could be divided without multiplicity, and his guidance was invaluable. The creation of the Mechanical Engineering Research Laboratory became one of his principal interests in later years, and the fact that the pattern of its organization has not been changed since it started has confirmed the wisdom of his views and outlook.

Sir Henry Guy was naturally chosen as the first chairman of the Mechanical Engineering Research Board, and his kindly and tolerant manner in the chair and the sincerity of his desire to convert those who differed from him, or to be himself converted, helped the new organization to surmount successfully its teething troubles. Even during the period when his health was causing anxiety, nothing gave him greater pleasure than to hear from time to time of its success.

He served as secretary of the Institution of Mech. anical Engineers during the period 1942-51.

A. MoCANCE

\section{Mr. C. F. Charter, O.B.E.}

Cecil Fremerick Charter died in London after a brief illness on January 27. He was then director of Soil and Land-Use Survey in the Gold Coast. That country has lost a good friend, a good organizer and an outstanding scientist.

Charter was educated at the Lowestoft Secondary School and at Trinity Hall, Cambridge. After teaching at the Tientsin Grammar School in North China and at the Antigua Grammar School, Charter accepted an invitation to undertake a study of the soils of Antigua and Barbuda. Charter's report on the soil survey of Antigua and Barbuda published in 1937 was reprinted in 1947 ; in collaboration with P. E. Turner he published in 1939 observations on soils of sugar estates in Trinidad. During 1933-44 he was local scientific officer of the Antigua Sugar Cane Investigation Committee. In 1940 he visited British Honduras and wrote an illuminating report on the soils, many of which are impoverished by long exposure to heavy rain. Charter described as a maturity sequence the soils formed on non-calcareous alluvium of various ages. The alluvium covers a wide area and carries swamp forest, well-drained broad-leaf forest, conifers or poor savannah. of these, the last two indicate moderate or severe impoverishment accompanied by development of a heavy, feebly permeable, brightly mottled subsoil.

In 1944 Charter was appointed soil chemist in the Gold Coast Department of Agriculture and worked in the West African Cocoa Research Institute. In 1949 he was promoted chief soil scientist of the Soil Survey Division, Department of Agriculture. In 1951 he was made director of a newly created Department of Soil and Land-Use Survey and was made O.B.E. He paid brief visits to the Belgian Congo, South Africa, Tanganyika and British Guiana in 